\title{
Temporal trend of leprosy in a region of high endemicity in the Brazilian Northeast
}

\author{
Tendência temporal da hanseníase em região de alta endemicidade do Nordeste brasileiro \\ Tendencia temporal de la lepra en región de alta endemicidad del Nordeste brasileño
}

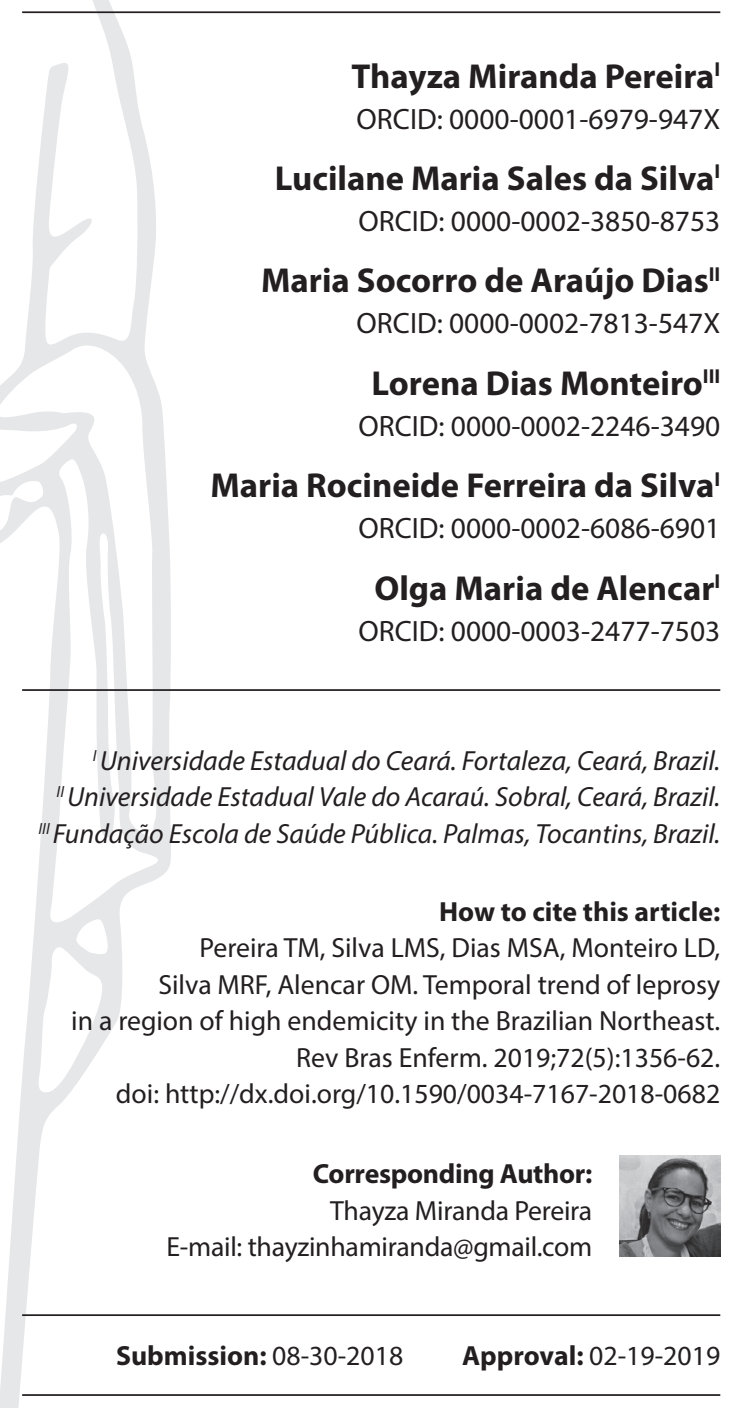

\begin{abstract}
Objective: to analyze the temporal trend and epidemiological patterns of leprosy indicators in Sobral, a municipality countryside of the state of Ceará, from 2001 to 2016. Method: a time series study based on data from the Department of Informatics of the Unified Health System. The time trend analysis was performed using the join point regression model. Results: There were 2,220 new cases of leprosy in Sobral from 2001 to 2016. Of these, $158(7.2 \%)$ in children younger than 15 years of age, the proportion of new male cases was $52.8 \%(1,162)$, cases with grade 2 were $7.0 \%(156)$, and proportion of cases diagnosed by contact examination 5.7\% (126). Final considerations: leprosy remains hyperendemic in adults and children, demonstrating the character of neglected disease. Analysis of the temporal trend allowed to verify that the instability in the detection coefficients, reflect operational problems in the organization of the services

Descriptors: Leprosy; Nursing; Epidemiology; Public Health; Neglected Diseases.
\end{abstract}

\section{RESUMO}

Objetivo: Analisar a tendência temporal e padrões epidemiológicos dos indicadores da hanseníase em Sobral, município do interior do estado do Ceará, no período de 2001 a 2016. Método: Estudo de séries temporais baseado em dados provenientes do Departamento de Informática do Sistema Único de Saúde. Análise da tendência temporal foi realizada por meio do modelo de regressão joinpoint. Resultados: Foram registrados 2.220 casos novos de hanseníase e residentes em Sobral de 2001 a 2016. Desses, 158 (7,2\%) em menores de 15 anos, sendo a proporção de casos novos do sexo masculino de $52,8 \%$ (1.162), de casos com grau 2 de 7,0\% (156) e proporção de casos diagnosticados por exame de contatos de 5,7\% (126). Conclusão: A hanseníase se mantém hiperendêmica em adultos e crianças, demonstrando o caráter de doença negligenciada. Análise da tendência permitiu verificar que a instabilidade nos coeficientes de detecção reflete problemas operacionais na organização dos serviços.

Descritores: Hanseníase; Enfermagem; Epidemiologia; Saúde Pública; Doenças Negligenciadas.

\section{RESUMEN}

Objetivo: analizar la tendencia temporal y los patrones epidemiológicos de los indicadores de lepra en Sobral, municipio del interior del Estado de Ceará, desde 2001 hasta 2016. Método: se trata de un estudio de series temporales basado en datos del Departamento de Informática del Sistema Único de Salud. El análisis de la tendencia temporal se realizó a través del modelo de regresión joinpoint. Resultados: entre 2001 y 2016 se registraron 2.220 nuevos casos de lepra en residentes de Sobral. De éstos, el 7,2\% (158), en niños menores de 15 años; la proporción de nuevos casos del sexo masculino era del 52,8\% (1.162), la proporción de casos con grado 2, del 7,0\% (156) y la proporción de casos diagnosticados por examen de contacto, del 5,7\% (126). Conclusión: la lepra sigue siendo hiperendémica en adultos y niños, lo que demuestra negligencia con respecto a esta enfermedad. El análisis de la tendencia comprobó que la inestabilidad en los coeficientes de detección refleja problemas operacionales en la organización de los servicios.

Descriptores: Lepra; Enfermería; Epidemiología; Salud Pública; Enfermedades Descuidadas. 


\section{INTRODUCTION}

Leprosy is a neglected disease that remains an object of public health action due to its magnitude and to affect the economically active age group with strong potential to trigger deformities and physical disabilities ${ }^{(1-2)}$. Early diagnosis and treatment with multidrug therapy (MDT) remain the main strategies for the control of leprosy ${ }^{(3-4)}$.

The impact of neglected tropical diseases is not limited to morbidity and mortality; due to its complexity, has affected a significant portion of society, leading to the permanence of stigma, to social exclusion, and the debate and interventions on health inequities ${ }^{(5-6)}$.

In this context, Brazil adopted as strategies: increased early detection, timely and appropriate treatment, health education actions, contact surveillance, prevention and treatment of disabilities $^{(7)}$.

In 2017, approximately 210,671 new cases of leprosy were registered in the world, with Brazil accounting for $12.76 \%$ of the cases. The general detection in the country was $12.94 / 100$ thousand inhabitants (26,875), with $6.4 \%$ (1,718 cases) being in children under 15 years of age, which points to the active movement of the disease ${ }^{(8)}$.

Ceará occupies the $6^{\text {th }}$ position in Brazil with the highest detection coefficient and the $4^{\text {th }}$ in the northeast region. In 2017, 1,555 new cases were diagnosed, with a detection coefficient of $17.24 / 100.000$, considered high (10.00 to $19.99 / 100$ thousand) according to WHO parameters ${ }^{(8-9)}$.

Analyzing the spatialization of leprosy cases diagnosed in 2017 in Ceará, it is observed that of the 184 existing municipalities, 05 are classified as hyperendemic (detection coefficient greater than 40 cases per 100 thousand inhabitants). The municipality of Sobral, with general detection coefficient in 2017 of 35,00/100,000 considered very high, according to WHO parameters ${ }^{(8-9)}$.

Despite efforts at early diagnosis in Brazil, there is still an important contingent of people with physical disabilities for leprosy every year. Thus, early diagnosis, correct management of leprosy and neuritis reactions, the practice of self-care and post-discharge follow-up, can avoid negative consequences, such as an increased risk of neural damage ${ }^{(10)}$ and therefore minimize the stigma associated with the disease.

The incorporation of surveillance and leprosy control actions in primary care through the Family Health Strategy (FHS) is considered key to effective and efficient disease control, with the challenge of ensuring that all people regardless of their place of residence, equal opportunity to be diagnosed and treated ${ }^{(6,11)}$.

The worldwide situation of leprosy emphasizes the need for actions sustained by political commitment, aiming at reaching a population in a situation of social vulnerability, promoting reflection on equity and integrality in health and in the process of health care $^{(2-3,5,12)}$.

\section{OBJECTIVE}

To analyze the temporal trend and epidemiological patterns of leprosy indicators in Sobral, a municipality in the countryside of the state of Ceará, from 2001 to 2016.

\section{METHOD}

\section{Ethical aspects}

This study is one paper from the $\mathrm{PhD}$ thesis entitled "Mãos que afagame afastam": redes sociais do cuidado às pessoas com hanseníase, held in the municipality of Sobral-Ce. The study was approved by the Research Ethics Committee of the State University of Ceará.

\section{Design, setting and study period}

This is a time-series study based on data from the Department of Informatics of the Unified Health System (DATASUS), with new leprosy cases from July to August 2017.

The study was conducted in Sobral, which is located in the Northwest region of the State of Ceará and is approximately 235 $\mathrm{km}$ from the capital of Ceará. Sobral is a predominantly urban municipality with economy focused on industry. It has a population of 205,529 inhabitants in 2017, with a predominance of the female population ${ }^{(13)}$. (Figure 1).

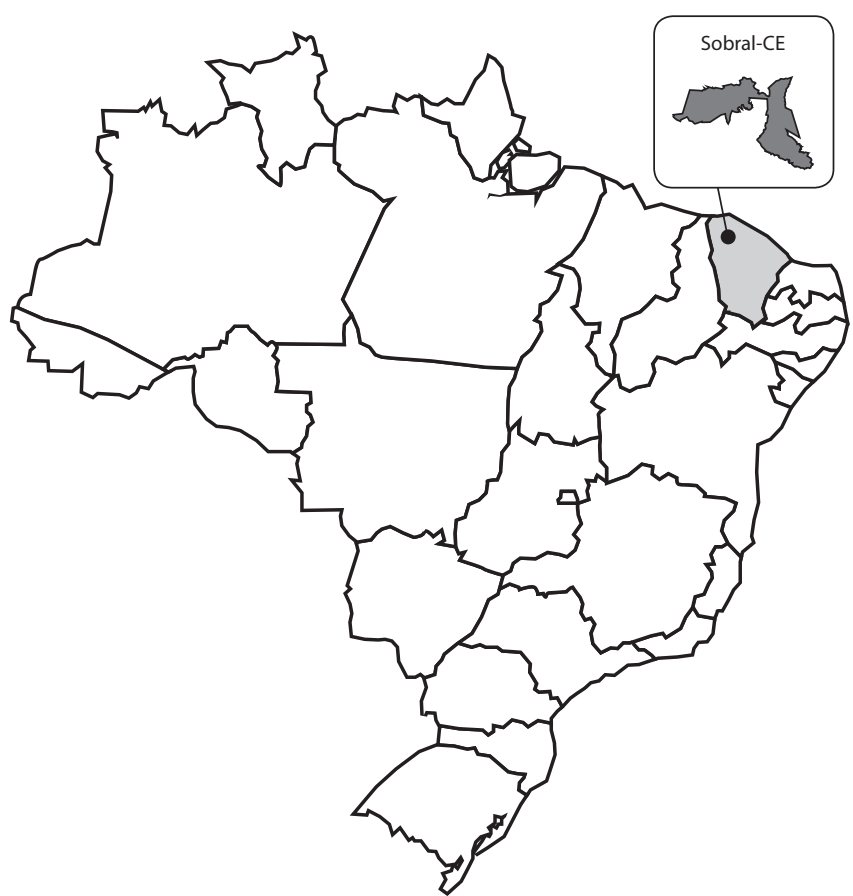

Figure 1 - Geographical location of the municipality of Sobral in the state of Ceará and Brazil

Sobral was chosen to be one of the municipalities with wellstructured health services, with coverage of $100 \%$ Family Health Strategy (FHS) teams and because it is considered a reference in the macro-region for health in the State, given the organization of the municipal system. Despite all this structure, the municipality with regard to epidemiological indicators of leprosy presents with high rates of endemicity.

\section{Study population}

All new cases of leprosy in the municipality of Sobral, state of Ceará, from 2001 to 2016, totaling 2,220 cases were included. 
Data were obtained from the Department of Informatics of the National Health System (DATASUS) of the Ministry of Health, from the compulsory notification sheets consisting of a standardized form with sociodemographic and clinical information filled out by health professionals. The database is in the public domain available on the website http://datasus.saude.gov.br/.

A case of leprosy has been defined by the World Health Organization (WHO) as the person presenting clinical signs of the disease and requiring specific leprosy treatment. This data may contain possible duplicate records.

Population data were obtained from the Brazilian Institute of Geography and Statistics (IBGE) based on data from the state population censuses (2010) and population estimates for the intercensity years (2001-2009 and 2011-2016) ${ }^{(13)}$.

\section{Study protocol - Analysis of results}

For descriptive analysis, we selected the variables according to case records per year. The selected indicators were those recommended by the national leprosy evaluation and monitoring program: General detection coefficient (indicates the magnitude of the disease), detection coefficient in children under 15 years of age (indicates the active transmission of the disease); proportion of multibacillary cases (indicates late diagnosis); proportion of paucibacillar cases (indicated early diagnosis) detecting mode (indicating the ability of services for diagnosis) and the proportion of new cases of grade 1 and 2 disability among all new cases detected during the year, which are applied to evaluate the delay in diagnosis as an indicator of the quality of case detection activities ${ }^{(7)}$.

For the temporal trend analysis the leprosy indicators, the detection coefficients were calculated from the IBGE population estimates for the studied years. The municipality of Sobral was used as geographical unit of analysis in the state of Ceará. The analysis of temporal trends for the period of 16 years of observation was performed through the join point regression model to calculate the annual increment. The objective of this analysis was to identify a significant change in the linear trend (on a log scale) during the study period, from 2001 to $2016^{(14)}$. APC analysis uses inflection points based on an algorithm that tests whether a multi-line segment is significantly better than a straight line or a line with fewer segments. The join point regression analysis joins a series of straight lines on a logarithmic scale to detect the trend of the annual indicator value.

It was considered the year of occurrence as an independent variable and, as dependent variables, the leprosy indicators selected. The analysis started with the minimum number of join points (for example, 0 join point, which is a straight line) and then one or more join points were tested to see if they were significant and if so, they would be included in the model. In this test up to 2 join points were achieved. Each significant join point, which indicated a change in slope, was retained in the final model. To describe linear trends by period, the Annual Percent Change (APC) was calculated for each of these trends with a regression line adjusted for the natural logarithm of the indicators. In cases where more than one slope was identified, the Average Annual Percentage Change (AAPC) was also calculated over the entire period (when available), based on an underlying join point model. The AAPC was estimated as the weighted geometric mean of the $A P C s$, with the weights equal to the length of each segment in the time interval ${ }^{(14)}$. An increase in the indicators was considered when the trend was growth and the minimum value of the confidence interval was greater than 0 (zero). Conversely, a reduction was considered when there was a decline in trend and the maximum value of the confidence interval was below 0 (zero). A stability was defined when the confidence interval included zero.

The join point regression analyzes were performed using the Join point Regression Program version 4.1.0 (US National Cancer Institute, Bethesda, MD, USA). The calculations of the indicators as well as the preparation of the tables were done in Microsoft Excel worksheets.

\section{RESULTS}

In the period from 2001 to 2016, 2,220 new cases of leprosy were registered and they were residents of Sobral. Of these, 158 (7.2\%) were in children under 15 years of age, the proportion of new male cases was $52.8 \%(1,162)$, the proportion of cases assessed for the degree of physical disability was 89 people. The proportion of cases with grade 2 was $7.0 \%$ (156), the proportion of cases diagnosed by contact examination was $5.7 \%$ (126), (Table 1).

Table 1 - Epidemiological and operational indicators of leprosy assessed from 2001 to 2016 in the municipality of Sobral, Ceará, Brazil

\begin{tabular}{|c|c|c|c|c|c|c|c|c|c|c|c|c|c|c|c|c|}
\hline Variables & 2001 & 2002 & 2003 & 2004 & 2005 & 2006 & 2007 & 2008 & 2009 & 2010 & 2011 & 2012 & 2013 & 2014 & 2015 & 2016 \\
\hline General Detection Coefficient & 111.0 & 115.4 & 277.1 & 139.9 & 59.6 & 62.0 & 65.6 & 71.1 & 57.6 & 50.5 & 45.6 & 52.8 & 45.0 & 44.6 & 41.1 & 31.9 \\
\hline Coefficient detection $<15$ years & 23.4 & 24.8 & 41.8 & 24.0 & 13.2 & 8.1 & 28.8 & 14.5 & 18.2 & 18.3 & 18.1 & 9.9 & 13.4 & 9.8 & 13.9 & 8.0 \\
\hline$\%$ healed & 91.5 & 89.2 & 87.7 & 84.1 & 95.1 & 89.9 & 91.4 & 93.0 & 87.6 & 94.7 & 90.8 & 92.2 & 89.9 & 93.3 & 94.0 & 86.2 \\
\hline$\%$ male & 51.7 & 47.3 & 45.6 & 53.6 & 50.5 & 55.0 & 57.8 & 57.8 & 60.0 & 52.6 & 55.2 & 52.0 & 57.3 & 51.7 & 59.0 & 58.5 \\
\hline$\%$ female & 48.3 & 52.7 & 54.4 & 46.4 & 49.5 & 45.0 & 42.2 & 42.2 & 40.0 & 47.4 & 44.8 & 48.0 & 42.7 & 48.3 & 41.0 & 41.5 \\
\hline$\%$ PB & 36.4 & 41.9 & 11.9 & 21.5 & 51.5 & 48.6 & 43.1 & 50.8 & 33.3 & 41.1 & 36.8 & 51.0 & 38.2 & 38.2 & 28.9 & 36.9 \\
\hline$\% \mathrm{MB}$ & 63.6 & 58.1 & 88.1 & 78.5 & 48.5 & 51.4 & 56.9 & 49.2 & 66.7 & 58.9 & 63.2 & 49.0 & 61.8 & 61.8 & 71.1 & 63.1 \\
\hline$\%$ assessed at diagnosis & 90.3 & 89.8 & 91.4 & 93.1 & 77.7 & 77.1 & 82.8 & 75.0 & 73.3 & 97.9 & 95.4 & 94.1 & 80.9 & 96.6 & 98.8 & 100.0 \\
\hline$\%$ grade $o$ & 55.7 & 62.9 & 55.5 & 67.4 & 66.0 & 63.3 & 47.4 & 54.7 & 38.1 & 60.0 & 59.8 & 61.8 & 55.1 & 53.9 & 68.7 & 67.7 \\
\hline$\%$ grade 1 & 25.0 & 21.5 & 28.4 & 20.2 & 8.7 & 10.1 & 23.3 & 18.8 & 27.6 & 26.3 & 29.9 & 26.5 & 21.3 & 34.8 & 16.9 & 21.5 \\
\hline$\%$ grade 2 & 9.7 & 5.4 & 7.5 & 5.6 & 2.9 & 3.7 & 12.1 & 1.6 & 7.6 & 11.6 & 5.7 & 5.9 & 4.5 & 7.9 & 13.3 & 10.8 \\
\hline$\%$ cases diag. by referral & 43.2 & 43.0 & 26.0 & 27.9 & 39.8 & 54.1 & 36.2 & 18.8 & 34.3 & 31.6 & 36.8 & 40.2 & 31.5 & 42.7 & 34.9 & 36.9 \\
\hline$\%$ cases diag. by spontaneous demand & 40.3 & 41.4 & 48.9 & 51.1 & 48.5 & 41.3 & 52.6 & 62.5 & 61.9 & 61.1 & 54.0 & 48.0 & 57.3 & 49.4 & 50.6 & 52.3 \\
\hline$\%$ population tests diagnosis & 0.6 & 4.8 & 9.0 & 7.3 & 4.9 & 2.8 & 6.9 & 11.7 & 1.0 & 2.1 & 4.6 & 5.9 & 3.4 & 1.1 & 12.0 & 7.7 \\
\hline$\%$ cases diag. by collective examination & 1.7 & 5.4 & 11.2 & 12.9 & 3.9 & 0.9 & 1.7 & 6.3 & 1.0 & 2.1 & 2.3 & 2.0 & 4.5 & 3.4 & 2.4 & 1.5 \\
\hline
\end{tabular}


Table 2 - Trend of the epidemiological and operational indicators of leprosy according to a regression analysis of the joinpoint in the municipality of Sobral state of Ceará, Brazil, 2001-2016

\begin{tabular}{|c|c|c|c|c|c|c|}
\hline \multirow[t]{2}{*}{ Indicators } & \multicolumn{3}{|c|}{ Annual Percentage Change (APC) } & \multicolumn{3}{|c|}{ Average Annual Percentage Change (AAPC) } \\
\hline & Period & APC & $95 \% \mathrm{Cl}$ & Total period & AAPC & $95 \% \mathrm{Cl}$ \\
\hline \multirow[t]{3}{*}{ General population detection/100,000 inhab. } & $2001-2003$ & $59.6^{*}$ & 28.1 a 98.8 & 2001 a 2016 & $-5.7^{*}$ & $-10.4 a-0.8$ \\
\hline & $2003-2006$ & $-36.8^{*}$ & -50.6 a -19.1 & & & \\
\hline & $2006-2016$ & $-4.3^{*}$ & $-6.6 a-2.0$ & & & \\
\hline Detection $<15$ years $/ 100,000$ inhabitants & $2001-2016$ & $-6.9^{*}$ & -10.9 a -2.7 & $2001-2016$ & $-6.9 *$ & $-10.9 a-2.7$ \\
\hline$\%$ Male & $2001-2016$ & $1.3^{*}$ & 0.4 a 2.2 & $2001-2016$ & $1.3^{*}$ & 0.4 a 2.2 \\
\hline$\%$ Female & $2001-2016$ & $1.5^{*}$ & $-2.4 a-0.5$ & $2001-2016$ & $1.5^{*}$ & $-2.4 a-0.5$ \\
\hline \% Paucibacilares & $2001-2016$ & 2.2 & -2.7 a 7.2 & $2001-2016$ & 2.2 & -2.7 a 7.2 \\
\hline \multirow[t]{3}{*}{$\%$ Multibacilares } & $2001-2003$ & 22.5 & -6.3 a 60.1 & $2001-2016$ & 0.9 & -5.3 a 7.6 \\
\hline & $2003-2006$ & -15.5 & -38.5 a 16.1 & & & \\
\hline & $2006-2016$ & 2.4 & -0.5 a 5.5 & & & \\
\hline$\%$ healed & 2006-2016 & 0.3 & -0.1 a 0.7 & $2006-2016$ & 0.3 & -0.1 a 0.7 \\
\hline$\%$ cases assessed as to the degree of incapacity & $2001-2016$ & 0.3 & -0.8 a 1.4 & $2001-2016$ & 0.3 & -0.8 a 1.4 \\
\hline$\%$ Grade 0 & $2001-2016$ & -0.2 & -1.7 a 1.3 & $2001-2016$ & -0.2 & -1.7 a 1.3 \\
\hline$\%$ Grade 1 & $2001-2016$ & 0.2 & -2.7 a 3.2 & $2001-2016$ & 0.2 & -2.7 a 3.2 \\
\hline$\%$ of cases with grade 2 & $2001-2016$ & 2.0 & -2.5 a 6.8 & $2001-2016$ & 2.0 & -2.5 a 6.8 \\
\hline Grade $2 / 100,000$ inhab. & $2001-2016$ & $-9.6^{*}$ & $-15.4 a-3.4$ & $2001-2016$ & $-9.6^{*}$ & $-15.4 a-3.4$ \\
\hline$\%$ cases diagnosed by referral & $2001-2016$ & 0.2 & -2.8 a 3.3 & $2001-2016$ & 0.2 & -2.8 a 3.3 \\
\hline \multirow[t]{2}{*}{$\%$ cases diagnosed by spontaneous demand } & $2001-2009$ & $4.5^{*}$ & 1.4 a 7.7 & $2001-2016$ & 0.9 & -1.5 a 3.5 \\
\hline & $2009-2016$ & -2.9 & -7.5 a 1.8 & & & \\
\hline$\%$ cases diagnosed by collective examination & $2001-2016$ & 0.1 & -6.3 a 6.9 & $2001-2016$ & 0.1 & -6.3 a 6.9 \\
\hline \multirow[t]{2}{*}{$\%$ cases diagnosed by contact examination } & $2001-2003$ & 137.8 & -63.4 a 1444.4 & $2001-2016$ & -1.5 & -22.0 a 24.5 \\
\hline & $2003-2016$ & $-14.0^{*}$ & -21.8 a -5.4 & & & \\
\hline
\end{tabular}

Note: Annual Percentage Change (APC); Average Annual Percentage Change (AAPC)

In the analysis of temporal trend, the detection coefficient in the general population showed a significant increase of $56.6 \%$ (APC: 59.6*; Cl: 28.1 to 98.8) between 2001 and 2003, it had a significant reduction of $-36.8^{*}$ (APC: $-36.8, \mathrm{Cl}$ : -50.6 to -19.1 ) in the 2003-2006 period, a significant third decline of $-4.3 \%$ was observed between 2006 and 2016 (APC: 4.3* , Cl: -6.6 to -2.0 ) and in the total period was $-5.7 \%$ (APC: -6.6 to -2.0$)$. The coefficient of detection in children under 15 years of age dropped significantly only for the total period and was -6.9\% (APC: $-6.9 *$, $\mathrm{Cl}:-10.9$ to -2.7$)$. There was a significant increase in the proportion of male $(1.3 \%)$ and female $(1.5 \%)$ cases. The diagnosis by contact examination had an increase of $138.8 \%$ between 2001 and 2003, but was not significant and in the period from 2003 to 2016 the fall was $-14.0 \%$ and statistically significant. There was a significant increase in the diagnosis by spontaneous demand between 2001 and 2009 of $4.5 \%$. The coefficient of detection of cases with grade 2 disability showed a significant decrease in the total period of $-9.6 \%$ (Table 2 ).

\section{DISCUSSION}

The data of this study, despite the downward trend in the last 16 years, point to the maintenance of the burden of the disease, since the high rates of detection of new cases of leprosy in the general population are still present in a systematic and persistent way in the epidemiological scenario. The occurrence of the disease in children under 15 years old, with parameters of hyperendemicity, according to the Ministry of Health ${ }^{(7)}$, ratifying the existence of active disease in the community. In Sobral endemic disease presents its magnitude, transcendence and strength sustained by the patterns of disease expression inequality over time, usually related to social vulnerabilities. It is possible to observe that in the period from 2001 to 2015 Sobral showed a pattern of hyperendemicity, being that in 2016 it is considered of very high endemicity. These trends may be related to operational issues of organization of health services, such as changes in management model, turnover of health professionals, reduction of active search, absence of specific protocol for contact surveillance, lack of continuing education practices among others.

Another factor that may be related to the disease trend is the increasing coverage of the family health strategy and the effective decentralization of leprosy control actions to the PHC network as indicative of improved access and the opportunity for early diagnosis. A study carried out in Fortaleza concluded that Basic Health Units present poor performance for diagnosis in children under 15 years of age ${ }^{(15)}$. A similar study in the Jequitinhonha Valley region, Minas Gerais, showed that the health services were not effective, and that only passive surveillance actions were limited, favoring the diagnosis of more advanced and severe forms of the disease ${ }^{(16)}$.

The higher prevalence of multibacillary cases indicates a high power of community transmissibility and late diagnosis ${ }^{(10)}$. Brazilian researchers point out the lack of training of health professionals to diagnose early disease, stigma and prejudice, as favoring for diagnosis in multibacillary forms. In this study, there was a higher prevalence of multibacillary cases throughout the period, reinforcing the need for effective surveillance actions in the territory ${ }^{(17)}$.

Leprosy affects men and women in a different and diversified way, which makes the need to offer access to these subjects in a 
different way ${ }^{(2,18)}$. Access to health services has been configured more centrally in health practices, leading to timely diagnosis and treatment with specific strategies for men and women ${ }^{(2)}$. In Sobral, as well as in other studies carried out in the Brazilian northeast, men are more vulnerable to contracting leprosy, contributing to the maintenance of the transmission dynamics of Mycobacterium. Leprae $^{(19)}$. The $1.5 \%$ increase in the number of cases in women in the total period (2001 to 2016) is due to the fact that women have more access to health services due to the logic of the organization of services ${ }^{(20)}$, in addition to itself playing the care role in the family and in society. In this sense, it emerges as a challenge to look at the male population in a differentiated way, making it the main subject, so as to insert it into the production of care, providing early diagnoses, preventing physical disabilities, as well as avoiding work absenteeism.

Considering its chronicity and the development of physical and psychosocial disabilities, the person affected by leprosy may require primary care, especially nursing, in a longitudinal manner, and access to the other levels of complexity is also required as a means of guaranteeing integrality of attention.

The degree of physical disability is an indicator that evaluates the effectiveness of timely and early detection of new leprosy cases and should be used in conjunction with detection rate $\mathrm{e}^{(7)}$. In Brazil, there has been a decrease in the detection of cases with grade 2 disability, following the downward tendency of the general detection of new cases $^{(7)}$. A study conducted in Brazilian municipalities corroborates findings from our study that demonstrate a higher prevalence of deformities in the male population. And yet the analysis of the evolution of the incapacities reveals a tendency to maintain the degree of incapacity at the moments of diagnosis and discharge ${ }^{(21-22)}$.

The presence of physical disability at the time of diagnosis denotes late diagnosis ${ }^{(7)}$. The degree of physical incapacity at the time of diagnosis in the study period shows instability in its tendency, however, it maintains Sobral classified as an area of high endemicity. Despite the significant fall in grade 2 disability in the period studied, $89.4 \%$ of people are still entering health services with some degree of disability, which demonstrates the inefficiency in capturing cases early.

Two surveys carried out in municipalities of hyperendemic states, responsible for the maintenance of the endemic disease in Brazil, showed that the coefficient of new cases with GIF 2 remained stable ${ }^{(23-24)}$, while Amorim's study ${ }^{(2)}$ carried out in Bahia showed a trend of significant growth of this coefficient and decreasing evolution in Paraíba ${ }^{(20)}$.

It is considered as a household contact, any person who has resided or resides with the patient, regardless of the time of social contact or operational classification, in addition to increasing vigilance for social contact, which also considers any person who lives or has lived together in a prolonged manner, in family or social relationships with the untreated patient. In this sense, contact surveillance contributes decisively to the control of the disease, breaking the chain of transmission, besides reducing the physical incapacities and the reactional episodes responsible for maintaining the stigma of the disease $\mathrm{e}^{(7,25)}$. Regarding the contact approach, this study pointed to a significant drop, which may be related to the fragility of health education actions and permanent surveillance, understanding that the disease has a long incubation period. A study carried out in Cacoal-RO verified that BCG vaccination is the main action performed in contact surveillance, without the complete dermatoneurological examination and that the contacts are not oriented to return to the health unit for a new evaluation. It was also identified that most of the contacts are evaluated by nurses and a minority by physicians, in addition to other professionals not qualified to testing. Therefore, it is necessary to have health education strategies with emphasis on leprosy-related guidelines and the importance of the contacts to carry out the examination with a view to the early diagnosis and reduction of the social impact of the disease.

\section{Limitations of the study}

By using SINAN secondary databases, there may be problems related to consistency and non-completeness of the data, besides the possibility of underreporting, which may interfere with the quality and quantity of the information. Even so, this study is of great relevance, since it analyzes the temporal trend of 16 years of a chronic disease with episodes of exacerbation, being able to collaborate with surveillance strategies of control actions and consequent improvement of the attention to people with leprosy.

\section{Contributions to the area of nursing}

This study contributes to strengthen the health surveillance actions of people affected by leprosy, considering this unusual analysis to emphasize the dialogue with the epidemiological situation of the disease, allowing professionals and managers to draw new strategies to reach the population with greater vulnerability to the disease. disease, strengthening, actions in the territories of care.

\section{CONCLUSION}

Leprosy remains a pattern of hyperendemicity in both adults and children, demonstrating the disease character neglected by public policies, perpetuating social vulnerabilities. The trend analysis shows that the instability in the detection coefficients does not reflect the epidemiology of the disease, but rather operational problems in the organization of the services to care for the disease in its acute form, also neglecting its chronicity, which requires new health care.

The disease affects men and women with a higher prevalence in the male population, which can be associated with the organizational form of health services. Therefore, the findings of this study invite us to reflect on the organization of health services for the real control of leprosy in the context of PHC, as well as the need to increase access to the male population in order to guarantee early diagnosis and prevent sequelae.

The challenges to disease control are of great complexity, since it pervades the biological issue of the disease process, since they are linked to the conditions of poverty, social inequalities and inequities in health. Therefore, coping requires substantial changes in the mode of health production that takes into account social determination.

The operational indicators evaluation of contacts and evaluation of degree of incapacitation agreed within the scope of 
epidemiology services point to the need to improve the quality of control actions developed by the SUS network. The evaluation of contact and evaluation of the degree of incapacities are decisive strategies for improving the care of the people affected by leprosy.

The evidence from this study indicates the need for new research that addresses the dynamics of transmission in areas considered to be of greater social vulnerability and consequently of high endemicity and low resolution of health services for timely prevention, diagnosis and treatment. We suggest the use of operational health research since this method is strategic for the strengthening of network care, especially when considering the complexity of the elimination of leprosy as a public health problem.

\section{REFERENCES}

1. Ministério da Saúde (BR). Secretaria de Vigilância em Saúde. Departamento de Vigilância de Doenças e Agravos não Transmissíveis e Promoção da Saúde. Saúde Brasil 2017: uma análise da situação de saúde e os desafios para o alcance dos objetivos de desenvolvimento sustentável [Internet]. Brasília (DF); 2018 [cited 2018 Jul 20]. 426 p. Available from: http://bvsms.saude.gov.br/bvs/publicacoes/saude_ brasil_2017.pdf

2. Souza EA, Ferreira AF, Boigny RN, Alencar CH, Heukelbach J, Martins-Melo FR, et al. Leprosy and gender in Brazil: trends in an endemic area of the Northeast region, 2001-2014. Rev Saúde Pública. 2018; 52: 20. doi: 10.11606/s1518-8787.2018052000335

3. World Health Organization-WHO. Global leprosy update, 2017: reducing the disease burden due to leprosy. Weekly Epidemiological Record [Internet]. N. 35, 2018[cited 2018 Nov 19];93:445-56. Available from: http://www.who.int/wer

4. World Health Organization-WHO. Global leprosy strategy 2016-2020: Accelerating towards a leprosy-free world[Internet]. 2016 [cited 2018 Jul 20]. Available from: http://apps.searo.who.int/PDS_DOCS/B5233.pdf

5. Lopes VAS, Rangel EM. Hanseníase e vulnerabilidade social: uma análise do perfil socioeconômico de usuários em tratamento irregular. Saúde Debate. 2014;38(103):817-29. doi 10.5935/0103-1104.20140074

6. T. van't Noordende. Towards a toolkit for cross-neglected tropical disease morbidity and disability assessment. Int Health. 2016; 8 (Suppl 1): i71-i81.doi: https://doi:10.1093/inthealth/ihw006

7. Ministério da Saúde (BR). Secretaria de Vigilância em Saúde. Departamento de Vigilância das Doenças Transmissíveis. Diretrizes para vigilância, atenção e eliminação da Hanseníase como problema de saúde pública: manual técnico-operacional[Internet]. Brasília:(DF). 2016 [cited $2018 \mathrm{Jul}$ 20];58 p. Available from: http://portalarquivos2.saude.gov.br/images/pdf/2016/fevereiro/04/diretrizes-eliminacaohanseniase-4fev16-web.pdf

8. Ministério da Saúde (BR). Secretaria de Vigilância em Saúde. Departamento de Vigilância das Doenças Transmissíveis Coordenação Geral de Hanseníase e Doenças em Eliminação. Banco de dados do programa: 2017(SINAN Nacional). Brasília (DF), 2018.

9. Secretaria da Saúde do Estado do Ceará. Situação epidemiológica da hanseníase. Informe Epidemiológico Hanseníase. [Internet]. Janeiro de 2018. [cited 2018 Mar 10]. Available from: https://www.saude.ce.gov.br/wp-content/uploads/sites/9/2018/06/boletim _ hanseniase_05_09_2017.pdf

10. Barbosa JC, Ramos Junior AN, Alencar OM, Pinto MSP, Castro CGJ. Atenção pós-alta em hanseníase no Sistema Único de Saúde: aspectos relativos ao acesso na região Nordeste. Cad Saude Coletiva. 2014;22(4):351-8. doi: 10.1590/1414-462X201400040008

11. Rodrigues L, Lockwood DNJ. Leprosy now: epidemiology, progress, challenges, and research gaps. Lancet Infect Dis. 2011;11:464-470. doi: 10.1016/S1473-3099(11)70006-8

12. Rocha PR, David HMSL. Determinação ou determinantes? uma discussão com base na Teoria da Produção Social da Saúde. Rev Esc Enferm USP. 2015; 49(1):129-35. doi: 10.1590/S0080-623420150000100017

13. Instituto Brasileiro de Geografia e Estatística. Cidades: Sobral, Ceará [Internet]. 2016 [cited 2018 Jul 03]. Available from: https://cidades.ibge. gov.br/brasil/ce/sobral/panorama

14. Kim HJ, Fay MP, Feuer EJ, Midthune DN. Permutation tests for joinpoint regression with applications to cancer rates. Stat Med [Internet]. 2000[cited 2018 Aug19];19(3):335-51. Available from https://doi.org/10.1002/ (SICI)1097-0258(20000215)19:3\%3C335::AID-SIM336\%3E3.0.CO;2-Z

15. Barbosa JC, Ramos Jr AN, Alencar MJ, Castro CG. Pós-alta em Hanseníase no Ceará: limitação da atividade funcional, consciência de risco e participação social. Rev Bras Enferm. 2008;61(n.spe):727-33. doi: 10.1590/S0034-71672008000700012

16. Lana FCF, Amaral EP, Lanza FM, Lima PL, Carvalho ACN, Diniz LG. Hanseníase em menores de 15 anos no Vale do Jequitinhonha, Minas Gerais(BR). Rev Bras Enferm[Internet]. 2008 [cited 2018 Aug19];60(6):696-700. Available from: http://www.scielo.br/pdf/reben/v60n6/13.pdf

17. Martins PV, Iriart JAB. Itinerários terapêuticos de pacientes com diagnóstico de hanseníase em Salvador, Bahia. Physis. 2014; 24(1): 273-289. doi: 10.1590/S0103-73312014000100015

18. Monteiro LD, Martins-Melo FR, Brito AL, Lima MS, Alencar CH, Heukelbach J. Leprosy trends in Tocantins, a hyperendemic State in the North of Brazil, 2001-2012. Cad Saúde Pública. 2015;31(5): 971-80. doi: 10.1590/0102-311X00075314

19. Porto MJ, Ferreira LNS, Pinheiro LMG, Almeida DJ. Análise dos números de casos notificados de hanseníase pelo SINAN na Bahia. Rev Enferm Contemp. 2015;4(2):137-144. doi: 10.17267/2317-3378rec.v4i2.455 
20. Campos MRM, Batista AVA, Guerreiro JV. Perfil clínico-epidemiológico dos pacientes diagnosticados com hanseníase na Paraíba e no Brasil, 2008 - 2012. Rev Bras Sci Saúde. 2018;22(1):79-86. doi: 10.22478/ufpb.2317-6032.2018v22n1.32152

21. Monteiro LD, Martins-Melo FR, Brito AL, Alencar CH, Heukelbach J. Physical disabilities at diagnosis of leprosy in a hyperendemic area of Brazil: trends and associated factors. Lepr Rev [Internet]2015 [cited 2016 mai9];86(3):240-50. Available from: https://www.lepra.org.uk/ platforms/lepra/files/lr/Sept15/Lep240-250.pdf

22. Ribeiro GC, Lana FCF, Diamantina M. Incapacidades físicas em hanseníase: caracterização, fatores relacionados e evolução. Cogitare Enferm. 2015;20(3):496-503. doi: 10.5380/ce.v20i3.41246

23. Freitas LR, Duarte EC, Garcia LP. Trends of main indicators of leprosy in Brazilian municipalities with high risk of leprosy transmission, 20012012. BMC Infect Dis. 2016;16:472. doi: 10.1186/s12879-016-1798-2

24. Brito AL, Monteiro LD, Ramos Jr AN, Heukelbach J, Alencar CH. Temporal trends of leprosy in a Brazilian state capital in Northeast Brazil: epidemiology and analysis by joinpoints, 2001 to 2012. Rev Bras Epidemiol. 2016;19(1):194-204. doi: 10.1590/1980-5497201600010017

25. Romanholo HSB, Souza EA, Ramos JAN, Kaiser Adélia CGCB, Silva IO, Brito AL et al . Surveillance of intradomiciliary contacts of leprosy cases: perspective of the client in a hyperendemic municipality. Rev Bras Enferm. 2018;71(1):163-169. doi: 10.1590/0034-7167-2016-0607 